\section{METODE PENAFSIRAN AYAT HUKUM AL-JASHSHASH}

\section{Khairuddin}

Program Pascasarjana UIN Suska Riau

Email:kh4iruddin@yahoo.co.id

\section{Abstract}

Al-Jashshash's Methods of Interpretation of Legal Verses: Along with the times, methods and style of interpretation (tafsir) was also developed. A book of commentary, Abkam al-Qur'an, written by Al-Jashshash is one of the books devoted to the legal texts, according to categories defined by AlJashshash himself (Jurisprudential/Fiqhy style). In interpreting the legal verses, Al-jashshash was combining interpretation bues; bi al-ma'tsur and bi al-ra'yi. The methods that used were: firstly, proposed subsection shall be construed; secondly, provide an explanation of meaning and etymology, confirmed by another verses of the Holy Quran, Hadith, and opinions of the Prophet's Companions; thirdly, to include jurisprudential issues that may be understood from the verse that interpreted; fourthly, expressed opinion among scholars and arguments that they used; and fifth, to analyze opinions of scholars that put forward, and determine his own opinion.

Keywords: Legal verses, Tafsir, Fiqh.

\section{Pendahuluan}

Kajian tafsir al-Qur'an telah ada semenjak berlangsungnya proses penurunan al-Qur'an itu sendiri. ${ }^{1}$ Ini menandakan bahwa ayat-

1 Penafsiran al-Qur'an pada periode awal merupakan penafsiran dengan corak bi al-ma'tsur, yakni menafsirkan ayat al-Qur'an dengan ayat al-Qur'an lainnya atau dengan penjelasan nabi Muhammad SAW yang kemudian dikenal dengan sunnah atau hadis. Salah satu contoh penafsiran ini adalah ketika rasulullah saw ditanya tentang pengertian kezaliman yang terdapat pada ayat 82 surat al-An'am, nabi saw menjawab dengan membacakan ayat al-Qur'an surat Luqman ayat 13. ayat al-Qur'an tidak dapat dipahami secara mandiri tanpa dukungan ayat yang lainnya, atau penjelasan nabi Muhammad saw yang berfungsi sebagai mubayyin. ${ }^{2}$ Seiring dengan perkembangan zaman, perkembangan metode dan corak penafsiranpun berkembang. ${ }^{3}$ Kitab tafsir Abkam al-Qur'an yang ditulis oleh al-Jashshash merupakan salah satu kitab tafsir yang khusus membahas avat-ayat hukum menurut kategori yang ditetapkan sendiri oleh al-Jashshash (corak fiqbiy). Tulisan ini bertujuan mengungkap beberapa pendekatan yang dilakukan oleh al-Jashshash dalam menafsirkan ayat-ayat hukum.

\section{Biografi al-Jashshash}

Al-Jashshash lahir pada tahun $305 \mathrm{H} / 917 \mathrm{M}$ dan wafat pada tahun $370 \mathrm{H} / 981 \mathrm{M}$. Adapun tempat kelahirannya terdapat perbedaan di kalangan penulis riwayat hidupnya. Menurut Dr. Muhammad Husain al-Dzahabi dalam bukunya Tafsir wa al-Mufassirun, al-Jashshash

Lebih lanjut lihat Yusuf Qardhawi, Kaifa Nata'ammalu Ma'a al-Qur'an al-'Azbim, alih bahasa oleh Abdul Hayyi al-Kattaniy, (Jakarta: Gema Insani Press, 1999), hlm. 288

2 Fungsi nabi Muhammad saw sebagai mubayyin tersebut dapat diketahui melalui firman Allah SW'T dalam al-Qur'an surat al-Nahl ayat 44 dan 64:

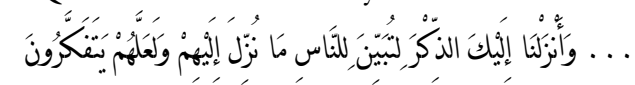

“...Dan Kami turunkan kepadamu al-Qur'an, agar kamu menerangkan kepada umat manusia apa yang telah diturunkan kepada mereka dan supaya mereka memikirkan".

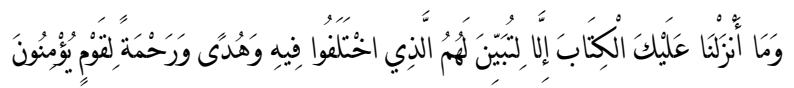

"Dan Kami tidak menurunkan kepadamu al-Kitab (al-Qur'an) ini, melainkan agar kamu dapat menjelaskan kepada mereka apa yang mereka perselisihkan itu dan menjadi petunjuk dan rahmat bagi kaum yang beriman".

3 Sampai hari ini terdapat empat metode penafsiran al-Qur'an yang berkembang, yakni, ijmaliy, tabliliy, maudhu'izy dan muqaran, sementara itu terdapat beberapa corak penafsiran, seperti; tafsir bi al-ma'tsur, bi al-ra'y, al-fiqhiy, al-kalamiy, alfalsafiy, al-shufiy, al-ilmiy, al-adabi dan al-ijtima'iy. Lihat M. Quraish Shihab, Membumikan al-Qur'an, (Bandung: Mizan, 1994), hlm. 72-73 
lahir di kota Bagdad (Irak). ${ }^{4}$ Sedangkan menurut team penyusun Ensiklopedi Hukum Islam, al-Jashshash lahir di Rayy, Persia (Iran). ${ }^{5}$

Al-Jashshash merupakan gelar yang dikenal di kalangan masyarakat. Nama lengkapnya adalah Abu Bakar Ahmad bin Ali alRaziy al-Jashshash. Panggilan al-Jashshash merupakan panggilan yang dinisbahkan kepada pekerjaannya sebagai tukang cat atau penjual cat. ${ }^{6}$ Kitab-kitab sejarah tentang tokoh fikih tidak memberikan informasi tentang kedua orang tua dan kehidupan masa kecilnya. Al-Jashshash hidup di zaman pertumbuhan dan perkembangan ilmu pengetahuan. Hal ini ia manfaatkan untuk menekuni ilmu pengetahuan dalam berbagai bidang. Ketekunannya dalam mempelajari ilmu pengetahuan tersebut terlihat dari banyaknya guru tempat ia belajar berbagai disiplin ilmu pengetahuan, baik pengetahuan umum maupun pengetahuan agama. Selain itu, juga dapat dilihat dari jumlah hasil karyanya dalam bidang ushul fiqh, fiqh, hadis dan tafsir. Sebagai ulama yang masyhur, alJashshash ramai dikunjungi pencinta ilmu pengetahuan. Dengan demikian al-Jashshash tentunya meninggalkan beberapa orang murid yang tidak diragukan keahliannya, di antaranya adalah; Abu 'Abdillah Muhammad bin Yahya al-Jurjani al-Hanafi, Abu Hasan Muhammad bin Ahmad al-Za'farani, Abu Ahmad bin Musa al-Khawarizmi, Ahmad ibn Muhammad ibn 'Amr, Abu Ja'far Muhammad bin Ahmad al-Nasafi dan Abu al-Hasan bin Muhammad bin Ahmad bin alThayyib al-Ka'ariy. ${ }^{7}$

Dalam kehidupan sehari-hari al-Jashshash dikenal sebagai seorang yang memiliki sifat-sifat terpuji, seperti; pemaaf, wara' dan zuhud. Ia sangat mementingkan pembinaan diri melalui

${ }^{4}$ Muhammad Husain al-Dzahabi, Tafsir wa al-Mufassirun, (Kairo: Daar alKutub al-Hadisah, 1976), Jilid 2, hlm. 438.

${ }^{5}$ Departemen Agama RI., Ensiklopedi Hukum Islam, Jakarta: PT. Ikhtiar Baru Van Hoeve, 1999), Jilid 3, hlm. 811.

${ }^{6}$ Dzahabi, Tafsir wa al-Mufassirun..., hlm. 438

${ }^{7}$ Mani’ Abdul Halim Mahmud, Manahij al-Mufassirin, (Kairo: Daar al-Kitab al-Mishr, 1978), hlm. 64 memperbanyak ibadah kepada Allah SWT. Kezuhudan al-Jashshash dapat dibuktikan dari sikapnya menolak jabatan Hakim Agung (qadbi al-qudha) yang ditawarkan kepadanya. ${ }^{8} \mathrm{Hal}$ ini juga diceritakan oleh Abu Bakar al-Ahbari sebagaimana dikemukakan oleh Mani' Abdul Halim Mahmud dalam bukunya Manabij al-Mufassirin sebagai berikut:

"Pada suatu hari hakim tinggi sengaja menjumpai saya untuk mencarikan orang yang pantas menggantikan beliau. Maka pada waktu itu saya mengusulkan agar jabatan tersebut diserahkan kepada al-Jashshash. Hakim Tinggi setuju dengan usulan saya atas pertimbangan ketenaran al-Jashshash di kalangan masyarakat serta kezuhudan dan sifat wara' yang ia miliki. Setelah itu permohonan Hakim Tinggi tersebut saya sampaikan kepada al-Jashshash, ia memberikan jawaban atas keengganannya. Beberapa waktu kemudian Hakim Tinggi menyuruh Abu Hasan bin Abu Umar untuk menemui dan membujuk al-Jashshash agar dapat menerima jabatan tersebut, namun al-Jashsash tetap memberikan jawaban atas keengganannya". 9

\section{Pendidikan al-Jashsash}

Telah dikemukakan di atas bahwa al-Jashshash hidup di zaman pertumbuhan dan perkembangan ilmu pengetahuan. Sebagai seorang pemuda yang memiliki semangat dan kemauan yang tinggi, ia banyak menghabiskan waktunya untuk mempelajari dan memperdalam ilmu pengetahuan. Ia menggunakan waktunya untuk belajar dari tempat kelahirannya sampai ke tempat-tempat lain di luar daerah. Selain itu ia juga mengadakan perjalanan dari satu kota ke kota lain untuk mencari ilmu pengetahuan dari ulama-ulama terkemuka pada waktu itu. Perjalanan pertama kali ia lakukan ke Ahwaz. Di Ahwaz ia belajar dari

\footnotetext{
${ }^{8}$ Dzahabi, Tafsir wa al-Mufassirun..., hlm. 438

${ }^{9}$ Mani’ Abdul Halim Mahmud, Manahij al-Mufassirin, hlm. 63
} 
dua orang ulama yang masyhur. Yaitu Abu al-Hasan Ubaidillah bin Hasan bin al-Karkhi dan kemudian kepada Abu Sahl al-Zujaj. ${ }^{10}$

Setelah berada berapa lama di Ahwaz, al-Jashsash melanjutkan perjalanannya ke Naisabur. Perjalanannya ke Naisabur atas saran Abu Hasan al-Karkhi. Di Naisabur ia berjumpa dengan Abu al-Abbas al'Asham al-Naisaburi, seorang pejabat Hakim Tinggi Naisabur dan juga sebagai ulama hadis. Al-Jashsash menimba ilmu pengetahuan begitu banyak dari Abu al-Abbas dalam bidang hadis dan Peradilan Islam. Ketekunan al-Jashsash belajar kepada Abu al-Abbas membawa hasil yang memuaskan, sehingga ia mampu menulis sebuah buku yang berjudul Adab al-Qadha', yaitu sebuah buku yang menggambarkan tata cara dan sopan santun dalam berperkara di pengadilan. Di Naisabur al-Jashsash berada cukup lama. Pada tahun $344 \mathrm{H}$ ia kembali ke Bagdad dan menetap di sana sampai akhir hayatnya. Ketekunan dan kesungguhan al-Jashsash dalam menuntut ilmu pengetahuan dari beberapa orang ulama besar sejak dari tempat kelahirannya sampai ke daerah-daerah lain menjadikannya sebagai seorang ulama yang berpikiran luas dan dikenal masyarakat pada waktu itu.

Adapun guru-guru yang mendidik dan membina al-Jashsash adalah:

1. Abu Hasan Ubaidillah bin Hasan al-Karkhi (260-340 H / 874-952 M). ia seorang tokoh ushul figh terkenal dalam mazhab Hanafi. Al-Karkhi adalah seorang guru yang pertama mendidik dan membina al-Jashsash. Ia berhasil menanamkan ilmu dasar terhadap al-Jashsash. Al-Karkhi pula yang berperan penting memotivasi al-Jashsash untuk menekuni dan mencintai ilmu pengetahuan. Selain itu al-Karkhi juga berhasil membina pola hidup al-Jashshash, sehingga alJashsash memiliki sifat-sifat terpuji seperti wara', pemaaf, zuhud yang akhirnya kezuhudan al-Jashsash dijuluki masyarakat seperti kezuhudan al-Karkhi.
2. Abu al-Abbas al-'Asham al-Naisaburi (321-405 H / 933-1014 M). ia adalah pejabat Hakim Tinggi di Naisabur. Abu alAbbas banyak berjasa dalam mendidik al-Jashsash di bidang hadis dan peradilan Islam. Ia mendidik al-Jashsash dalam ilmu teoritis maupun terapan. Belajar ilmu teoritis seperti hadis, al-Jashsash belajar secara formal sebagaimana muridmurid Abu al-Abbas yang lain. Dalam bidang peradilan Islam, selain belajar secara teoritis, Abu al-Abbas melibatkan langsung al-Jashsash untuk menyelesaikan perkara-perkara di Pengadilan. Dengan demikian al-Jashsash dapat menguasai ilmu peradilan Islam dengan matang.

Selain al-Karkhi dan Abu al-Abbas, masih banyak lagi ulama yang berjasa dalam mendidik al-Jashsash seperti; Abu Sahl al-Zujaj, Abu Sa'id al-Baza'i, Musa bin Nashr al-Razi, Abdullah bin Ja'far bin Faris al-Asbahani, Abu al-Qasim Sulaiman bin Ahmad al-Thabrani (w.360 H) dan Abdul Baqi bin Qani'.

Sebagai seorang ulama terkemuka al-Jashsash tentu tidak ingin kalau ilmu yang ia miliki hanya bermanfaat bagi dirinya sendiri. Tetapi ia ingin menyampaikannya kepada orang lain dan mewariskan kepada generasi berikutnya. Untuk mewujudkan hal ini, al-Jashsash menulis beberapa judul buku yang telah dikodifikasikan dan dapat dimanfaatkan masyarakat serta segenap pecinta ilmu pengetahuan sampai sekarang. Adapun karya-karya al-Jashsash adalah antara lain; Abkam al-Qur'an, Syarh Mukbtashar al-Karkhi, Syarh Mukbtashar alThahawi, Syarh al-Jami' al-Kabir li al-Imam Muhammad ibn Hasan alSyaibani, Syarb al-Jami' al-Shaghir wa al-Jami' al-Kabir, Jawab al-Masail, AlFushul fi al-Ushul, Adab al-Qadha' dan Usbul al-Fiqh.

\section{Profil Kitab Tafsir Ahkam al-Qur'an.}

${ }^{10}$ Dzahabi, Tafsir wa al-Mufassirun..., hlm. 438 
Kitab Abkam al-Qur'an merupakan karya monumental alJashsash. ${ }^{11}$ Kitab ini mendapat sambutan dan komentar dari ulama maupun masyarakat. Dr. Muhammad Husein al-Dzahabi menyebutkan 'kitab tafsir Abkam al-Qur'an karya al-Jashshash merupakan kitab tafsir ayat hukum yang sangat diperhitungkan, terutama di kalangan pengikut mazhab Hanafi. Kitab ini merupakan kitab pokok yang tersusun secara sistematis. Penafsiran ayat dalam kitab ini sesuai dengan susunan urutan surat dalam al-Qur'an. Meski demikian, al-Jashshash hanya menafsirkan ayat-ayat yang berkaitan dengan hukum saja. Penafsiran yang dilakukan al-Jashshash tidak hanya secara global, tetapi ia mengetengahkan masalah-masalah fiqhiyah serta perbedaan pendapat ulama dengan dalil-dalil yang rinci, sehingga terkesan seperti kitab fiqh muqaran". ${ }^{12}$

Dr. Abdul Halim Mahmud menjelaskan "kitab tafsir Abkam alQur'an karya al-Jashshash merupakan kitab tafsir ayat hukum pertama yang secara khusus membahas ayat-ayat hukum dalam al-Qur'an. Kitab ini menjadi dasar dan rujukan utama ulama lain dalam dalam menulis tafsir yang bercorak hukum, seperti Ibn 'Arabi, al-Qurtubi, alLukya al-Hirasi serta penulis tafsir ayat hukum lainnya. Dalam kitab ini dihimpun semua permasalahan hukum yang disusun perbab sesuai dengan kandungan ayat hukum yang ditafsirkan". ${ }^{13}$

Dalam kitab ini ayat hukum yang ditafsirkan al-Jashshash lebih banyak dan lebih luas. Hal ini karena tidak adanya kesepakatan ulama dalam menetapkan jumlah ayat hukum dalam al-Qur'an, dengan demikian penetapan ayat hukum tergantung pada sisi pandang masing-

11 'Allamah al-Maula Mushthafa ibn Abdillah al-Qusthanthiniy al-Hanafi, Kasyf al-Zhunun, (Beirut: Daar al-Fikr, 1994), jilid 1, hlm. 491

12 Dzahabi, Tafsir wa al-Mufassirun, hlm. 438-439

13 Abdul Halim Mahmud, Manahij al-Mufassirin, (Kairo: Daar al-Kitab alMishr, 1978), hlm. 64 masing ulama. ${ }^{14}$ Adapun kandungan hukum yang dibahas al-Jashshash dalam kitab Abkam al-Qur'an adalah sebagai berikut:

\section{Sumber Hukum Islam}

Sumber hukum Islam yang membahas: Kedudukan al-Qur'an dan sunnah sebagai sumber utama ajaran Islam, kehujjahan ijma', kebolehan melakukan analogi (qiyas), ijtihad, istihsan, problematika nasakh dan kedudukan hukum yang ditetapkan al-Qur'an.

\section{Hukum-hukum Ibadah}

Adapun hukum-hukum ibadah memuat: hukum sujud kepada selain Allah SW'T dan kewajiban mengingat Allah SWT. Thaharah dan shalat; wudhu', mandi junub, hukum orang yang janabah lewat di masjid, tayammum, waktu-waktu shalat, adzan, menghadap qiblat dalam shalat, kedudukan basmalah dalam al-Qur'an, hukum membaca al-fatihah dalam shalat, sujud dengan wajah, bacaan sujud, menangis dalam shalat, bacaan jahar dalam shalat dan do'a, shalat wustha, shalat dalam perjalanan, shalat khauf, shalat Jum'at, musafir pada hari Jum'at, qiyamullail. Zakat; syarat zakat, ancaman bagi orang yang tidak membayar zakat, orang-orang yang berhak menerima zakat, hukum menyerahkan zakat pada satu ashnaf, shadaqoh, infaq, hibah. Puasa dan i'tikaf, cara melihat bulan, qadha puasa Ramadhan, kebolehan menunda qadha puasa Ramadhan, makan, minum dan hubungan seksual di malam bulan Ramadhan, puasa sunat, hal-hal yang boleh dilakukan orang yang sedang i’tikaf. Haji dan qurban; kewajiban melaksanakan haji, hari-hari yang telah ditentukan, tata cara thawaf, thawaf ziarah, sa'i antara Shafa dan Marwa, hukum berburu bagi orang

14 Terdapat perbedaan pendapat di kalangan ulama tentang jumlah ayat hukum dalam al-Qur'an, menurut Thanthawi Jawhari dan lainnya sebanyak 150 ayat, menurut Ahmad Amin terdapat 200 ayat, menurut Ibn Arabi 400 ayat, menurut Abdul Wahab Khalaf 228 ayat dan menurut al-Ghazali, al-Razi, Ibn alJazaiy al-Kalbi dan Ibn Qudamah terdapat 500 ayat, sedangkan menurut Ibn Mubarak 900 ayat dan Abu Yusuf 1.110 ayat. Lihat Moh. Amin Suma, Pengantar Tafsir Abkam, (Jakarta: Rajawali Pers, 2001), hlm. 31-32 
yang sedang ihram, jual beli ketika pelaksanaan ibadah haji, hukum makan daging dam (denda), ziarah dan hukum menyebut nama Allah SWT ketika menyembelih binatang. Menguburkan orang yang meninggal dunia. Isti'adzah. Hukum orang musyrik masuk masjid.

\section{Hukum-hukum Muamalah}

Hukum-hukum mu'amalah mencakup: Hukum sihir dan kedudukan tukang sihir dalam syari'at Islam; larangan menyembunyikan ilmu dan kewajiban mengajarkan agama; kewajiban mendidik anak, pemeliharaan anak yatim, harta anak yatim, hukum menyerahkan harta kepada anak yatim yang masih kecil atau yang bodoh dan hukum makan harta anak yatim; transportasi laut dan bacaan basmalah ketika bepergian; dasar hukum kebolehan jual beli dan keharaman riba; gadai; hukum bermu'amalah dengan ahli dzimmah dan orang musyrik; kewajiban amar ma'ruf dan nahi munkar; larangan banyak bersumpah; berbakti kepada kedua orang tua.

\section{Hukum-hukum Ahwal al-Syakhshiyyah}

Hukum-hukum ahwal al-syakhshiyyah mencakup: perkawinan, tata cara pertunangan, wanita yang haram dikawini (muabbad dan muwaqqat), hukum menikahi wanita musyrik, wanita yang bersuami, wanita yang masih kecil, wanita ahli kitab, wanita hamba sahaya, wanita hamba sahaya kitabiyah, menikahi wanita hamba sahaya tanpa izin tuannya, wali dalam perkawinan, mahar, penambahan mahar, isteri menyerahkan mahar kepada suaminya, hak dan kewajiban suami isteri. Perceraian; nusyudz, syiqaq, ila', li'an, qadzaf, khulu', zhihar, jumlah thaqak, thalak sebelum nikah, saksi dalam perceraian, iddah wanita yang meninggal suaminya, iddah wanita yang masih haid, iddah wanita hamil, iddah wanita monopause, iddah wanita yang masih kecil, ruju', saksi dalam ruju', mut'ah bagi isteri yang diceraikan, hak tempat tinggal bagi isteri yang diceraikan dan biaya pemeliharaan anak.

\section{Hukum Kewarisan dan Wasiat}

Kewarisan dan wasiat: bahagian masing-masing ahli waris, kewarisan kakek dan cucu, kewarisan orang murtad, 'aul dan rad, musyarakah, 'ashabah, kalalah, wasiat, hukum berwasiat, wasiat kepada orang tua dan kerabat dekat, wasiat kepada ahli waris, hukum menukar wasiat dan saksi dalam wasiat.

\section{Hukum-hukum Jinayah dan Siyasah}

Hukum-hukum jinayah dan siyasah yang membahas: pembunuhan dan kifaratnya; pembunuhan sengaja, pembunuhan semi sengaja, pembunuhan tersalah, diat pembunuhan tersalah dan semi sengaja, ada atau tidaknya niat bagi pembunuhan sengaja, ukuran diat unta dan umurnya, diat selain unta, diat bagi orang kafir, qisas dan hukum-hukumnya, orang muslim berada di negara non muslim dan melakukan pembunuhan, hukum pemberontak (pembangkang) dan perlakuan kepadanya. Pencuri dan jarimahnya; hukum potong tangan, ukuran pencurian yang dilakukan potong tangan dan bagian tangan yang dipotong; Zina, hukum jilid dan rajam; Sumpah dan kifaratnya; larangan membuat majelis kezaliman; Peperangan; larangan lari dari peperangan, jihad, jihad dengan diri, harta dan ilmu, persiapan jihad, harta rampasan dan pembagiannya, bahagian kuda perang dan bahagian seperlima; Pengambilan pajak dari ahli kitab dan waktu pembayarannya; Kewajiban mentaati rasul dan pemimpin; Kewajiban melaksanakan amanah dan menghukum dengan adil; Suap, bentuk dan hukumnya; Berita orang fasiq; Keharusan menjawab bagi orang yang dipanggil ke pengadilan.

\section{Halal dan Haram}

Halal dan haram: Kebolehan makan binatang laut, daging keledai dan belalang; Keharaman bangkai, darah, daging babi, binatang yang disembelih bukan atas nama Allah SWT, binatang buas yang bertaring, burung yang berkuku tajam, biawak, burung yang mati terjatuh, minyak dan bulu bangkai, berjudi dan minum khamar; Larangan 
mengharamkan apa yang telah dihalalkan Allah SWT; Darurat dan ukurannya. ${ }^{15}$

\section{Metode Penafsiran Ayat Hukum al-Jashshash}

Al-Jashshash merupakan salah seorang mufassir yang membahas (menafsirkan) ayat-ayat yang berkenaan dengan hukum. Sebagai seorang mufassir yang ulet dan tangguh, ia mampu menafsirkan keseluruhan ayat-ayat hukum dalam al-Qur'an. Untuk mengetahui bagaimana metode penafsiran dan pemikirannya di bidang figh, perlu mengkaji dan meneliti pendapat-pendapat yang tertuang dalam karyanya. Sebagai jenjang untuk mengkaji dan mengetahui metode penafsiran dan pemikiran figh al-Jashshash, penulis mengemukakan beberapa metode penafsiran ayat al-Qur'an berikut contoh penafsirannya sesuai dengan apa yang dikemukakan al-Jashshash dalam Ahkam al-Qur'an.

\section{Pendekatan Tematik Tekstualis}

Sifat tekstualnya dalam memahami nash menghasilkan formulasi hukum yang berbeda dengan beberapa ulama. Hal ini dapat dilihat pada penafsiran ayat tentang wasiat kepada ibu bapak dan kerabat yang terdapat dalam surat al-Baqarah ayat 180. Menurut pandangan jumhur ulama, kandungan hukum dalam ayat ini telah di nasakhkan. Dengan demikian hukum wasiat kepada ibu bapak dan kerabat tidak berlaku. Sedangkan menurut al-Jashshash kandungan hukum ayat ini tetap berlaku karena tidak ada satu nashpun yang dapat diterima sebagai penasakhnya. Lebih lanjut ia menjelaskan bahwa nasakh dengan ayat kewarisan tidak dapat diterapkan dalam masalah ini, karena kandungan ayat wasiat dengan ayat waris dapat dikompromikan. Terlebih lagi kedua ayat tersebut mengandung materi hukum yang berbeda.

15 Al-Jashshash, Ahkam al-Qur'an, (Beirut: Daar al-Fikr, 1993), Jilid 1, 2 dan
Ulama Syi'ah Zaidiyah, Syi'ah Imamiyah, dan Syi'ah Isma'iliyah membolehkan wasiat terhadap ibu bapak dan kerabat, meskipun tanpa persetujuan ahli waris lainnya. Sedangkan Ibnu Hazm menjelaskan, sebagaimana dikutip Alyasa Abu Bakar, sekiranya orang meninggal sebelum berwasiat, maka ahli waris wajib mengeluarkan sebagian dari harta warisan sejumlah yang mereka aggap layak. Namun al-Muzni dan mazhab Zhahiri melarang wasiat kepada ahli waris sekalipun dibolehkan ahli waris lainnya. Sementara itu team penyusun buku alQuran dan tafsirnya mengemukakan pendapat Abu Muslim alAsfahani dan Ibnu Jarier al-Thabari yang tetap memberlakukan kandungan ayat 180 surat al-Baqarah tersebut.

Dalam masalah ila' al-Jashshash pola pikirnya bersifat tekstual dalam memahami "menunggu sampai empat bulan". Ia berpendapat bagi suami yang bersumpah ila' begitu habis masa empat bulan, maka secara otomatis thalak jatuh dan statusnya thalak bain tanpa dibarengi lagi dengan ucapan thalak dari suami yang juga tanpa ada keterlibatan hakim.

Dalam hal ini ia tampak nya sependapat dengan Ibnu Abbas, alTsauri, Hasan bin Shaleh dan Abu Hanifah, dengan demikian berbeda dengan imam Malik, Syafi'i dan Ahmad yang mengatakan waktu empat bulan tidak menyebabkan terjadinya thalak secara otomatis, tetapi suami diperintahkan untuk mengambil alternatif untuk kembali kepada isterinya atau menceraikannya. Kalau suami enggan menceraikan dan tidak kembali kepada isterinya maka hakimlah yang menceraikan keduanya.

Untuk melihat bagaimana al-Jashshash menggunakan metode ini dalam menafsirkan ayat hukum, dapat dilihat ketika menafsirkan ayat tentang wasiat wajibah dalam al-Qur'an. Wasiat yang dibahas dalam tulisan ini adalah mengenai wasiat terhadap ahli waris (ibu, bapak dan keluarga dekat/zawil furudh). Hal ini merupakan kajian dan penafsiran terhadap al-Qur'an surat al-Baqarah ayat 180-182: 


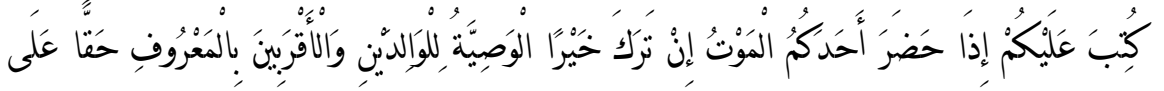

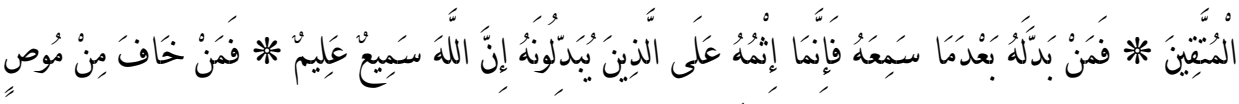

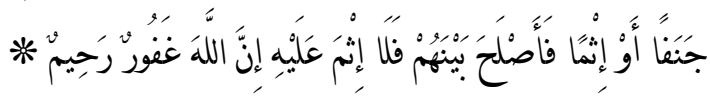

"Diwajibkan atas kamu, apabila seorang di antara kamu kedatangan (tanda-tanda) maut, jika ia meninggalkan harta yang banyak, berwasiat untuk ibu-bapa dan karib kerabatnya secara ma`ruf, (ini adalah) kewajiban atas orang-orang yang bertakwa. Maka barangsiapa yang mengubah wasiat itu, setelah ia mendengarnya, maka sesungguhnya dosanya adalah bagi orangorang yang mengubahnya. Sesungguhnya Allah Maha Mendengar lagi Maha Mengetahui. (Akan tetapi) barangsiapa khawatir terhadap orang yang berwasiat itu, berlaku berat sebelah atau berbuat dosa, lalu ia mendamaikan antara mereka, maka tidaklah ada dosa baginya. Sesungguhnya Allah Maha Pengampun lagi Maha Penyayang”. (Q.S. al-Baqarah: 180-182)

Dalam menafsirkan ayat 180 surat al-Baqarah ini, al-Jashshash berpegang teguh pada pemahaman tekstual ayat tersebut. Ia mengatakan, apabila seseorang memiliki banyak harta, wajib meninggalkan wasiat terhadap kedua orang tua (ibu dan bapak) dan keluarga terdekat. Al-Jashshash berpendapat seperti ini berdasarkan pemahamannya terhadap ayat tersebut dengan mengemukakan berbagai argumentasi sebagai berikut:

Pertama, membandingkan beberapa term yang digunakan pada ayat tentang wasiat dengan ayat lainnya dengan pendekatan tematik. Term pertama yang dipilih adalah كتب . Ayat tentang wasiat ini dimulai dengan term كتب yang tafsirnya adalah فرض artinya difardhukan/diwajibkan. Selanjutnya ia menjelaskan bahwa ada beberapa kewajiban umat Islam yang dalam al-Qur'an dengan menggunakan term كتب. Hal ini dapat dilihat dari beberapa ayat al-
Qur'an yang menggunakan term كتب yang menyatakan wajib. Sebagaimana tedapat pada ayat tentang kewajiban berpuasa;

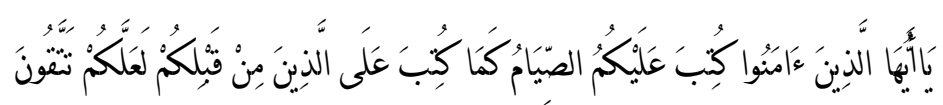

"Hai orang-orang yang beriman diwajibkan bagi kamu berpuasa sebagaimana telah diwajibkan kepada orang-orang sebelummu mudah-mudahan kamu menjadi orang yang bertaqwa". (Q.S. alBaqarah: 183)

Penggunaan term كتب juga terdapat pada ayat tentang kewajiban pelaksanaan qishash dalam pembunuhan;

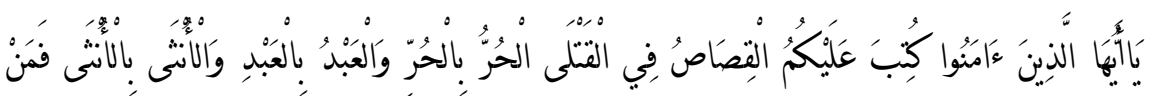

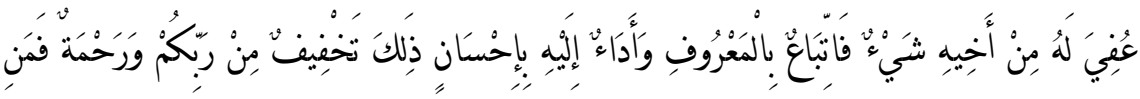

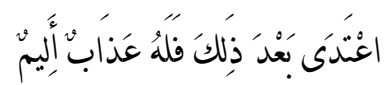

"Hai orang-orang yang beriman, diwajibkan atas kamu qishaash berkenaan dengan orang-orang yang dibunuh; orang merdeka dengan orang merdeka, hamba dengan hamba dan wanita dengan wanita. Maka barangsiapa yang mendapat suatu pema`afan dari saudaranya, hendaklah (yang mema`afkan) mengikuti dengan cara yang baik, dan hendaklah (yang diberi ma`af) membayar (diat) kepada yang memberi ma`af dengan cara yang baik (pula). Yang demikian itu adalah suatu keringanan dari Tuhan kamu dan suatu rahmat. Barangsiapa yang melampaui batas sesudah itu, maka baginya siksa yang sangat pedih". (Q.S. al-Baqarah: 178)

Juga dapat dilihat pada ayat tentang kewajiban shalat pada waktu telah ditentukan; 


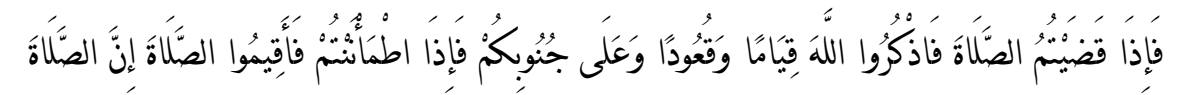

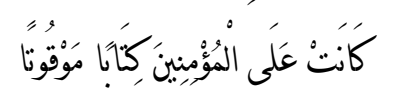

"Maka apabila kamu telah menyelesaikan shalat (mu), ingatlah Allah di waktu berdiri, di waktu duduk dan di waktu berbaring. Kemudian apabila kamu telah merasa aman, maka dirikanlah shalat itu (sebagaimana biasa). Sesungguhnya shalat itu adalah kewajiban yang ditentukan waktunya atas orang-orang yang beriman". (Q.S. an-Nisa': 103)

Dengan membandingkan beberapa ayat dalam al-Qur'an yang menggunakan term كتب dan semuanya menunjukkan wajib, maka jika pada ayat 180 surat al-Baqarah ini terdapat kata kutiba juga tentunya menyatakan wajib. ${ }^{16}$

Term kedua adalah المعروف. Dalam ayat tentang wasiat kepada ibu bapak dan kerabat terdapat pula term المعروف. Menurut alJashshash, penyebutan term المعروف ini bukan untuk menghilangkan kewajiban berwasiat, tetapi justru menambah kuatnya kewajiban berwasiat tersebut. Hal ini karena pengertian المعروف itu adalah keadilan, yakni tidak boleh lebih dari batas maksimal dan tidak boleh kurang dari batas minimal. Dengan demikian, kalau berbuat adil merupakan kewajiban, maka berbuat ma'ruf yang pengertiannya "keadilan" tentu juga wajib. Lebih lanjut al-Jashshash menjelaskan bahwa semua perintah Allah adalah ma'ruf bukan munkar. Semua orang dapat mengetahui bahwa lawan ma'ruf adalah munkar, berbuat munkar itu dilarang dan dicela oleh Allah SWT, dengan demikian apabila yang ma'ruf dalam ayat ini tidak dilaksanakan, maka berarti secara tidak langsung telah berbuat munkar. Telah dijelaskan sebelumnya bahwa yang munkar merupakan larangan Allah SWT. Pemahaman seperti ini

${ }^{16}$ Jashshash, Abkam al-Qur'an, jilid 1, hlm. 199 dianalisa al-Jashshash berdasarkan pengertian beberapa term المعروف yang terdapat dalam al-Qur'an, seperti;

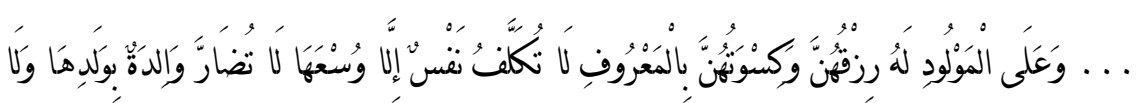

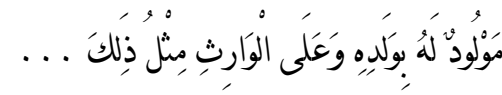

“...Dan kewajiban ayah memberi makan dan pakaian kepada para ibu dengan cara yang ma'ruf. Seseorang tidak dibebani melainkan menurut kadar kesanggupannya. Janganlah seorang ibu menderita kesengsaraan karena anaknya dan juga seorang ayah karena anaknya, dan warispun berkewajiban demikian... (Q.S. al-Baqarah: 233)

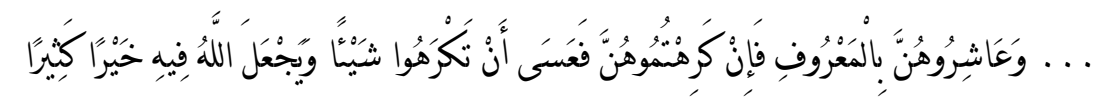

“... bergaullah dengan mereka secara patut. Kemudian bila kamu tidak menyukai mereka, (maka bersabarlah) karena mungkin kamu tidak menyukai sesuatu, padahal Allah menjadikan padanya kebaikan yang banyak. (Q.S. an-Nisa': 19)

Hal ini juga telah jelas bahwa memperlakukan isteri secara patut merupakan suatu kewajiban bagi suami.

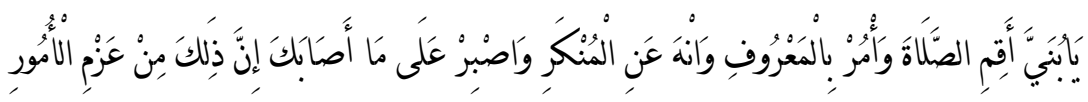

"Hai anakku, dirikanlah shalat dan suruhlah (manusia) mengerjakan yang baik dan cegahlah (mereka) dari perbuatan yang mungkar dan bersabarlah terhadap apa yang menimpa kamu. Sesungguhnya yang demikian itu termasuk hal-hal yang diwajibkan (oleh Allah). (Q.S.Luqman: 17)

Selain ayat yang telah dikemukakan diatas , masih ada lagi ayatayat al-Qur'an yang menggunakan kata ma'ruf, dilalahnya menunjukkan wajib. 
Masih pemahaman terhadap redaksi ayat, dalam ayat tentang wasiat ini terdapat kalimat حقا على المتقين Al-Jashshash mengatakan kalimat ini memiliki pengaruh penting dalam memeperkuat alasan wajibnya wasiat kepada orang tua dan keluarga terdekat bagi orangorang yang memiliki banyak harta. Taqwa kepada Allah SWT sesungguhnya merupakan suatu kewajiban. Hal ini juga tidak ada perbedaan di kalangan umat Islam. Begitu wasiat dalam ayat in dijadikan salah satu syarat untuk meraih ketaqwaan, berarti juga menjelaskan wajibnya wasiat. Adapun pen-takhsis-an keumuman makna ayat dengan kata muttaqin dalam pandangan sebagian ulama menurut al-Jashshash bukan untuk mengingkari kewajibannya dan bukan pula menjelaskan kewajibannya hanya untuk orang yang bertaqwa saja, tetapi menyatakan bahwa dengan berwasiat kepada ibu dan bapak serta kerabat terdekat tersebut merupakan salah satu sarana untuk mencapai dan meningkatkan ketaqwaan kepada Allah SWT dan juga sebagai salah satu cara membuktikan ketaqwaan seorang muslim dengan menjalankan wasiat tersebut. ${ }^{17}$ Dengan demikian jelaslah kewajiban berwasiat menurut dilalab ayat ini berdasarkan pemahaman

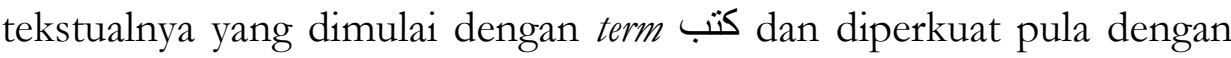
term المعروف dan kalimat حقا على المتقين .

Selain ayat tentang wasiat, pendekatan tematik tekstualis juga dapat dilihat ketika al-Jashshash menafsirkan ayat tentang ila'. Pembahasan tentang ila' merujuk kepada ayat al-Qur'an surat alBaqarah ayat 226 dan 227 yang berbunyi:

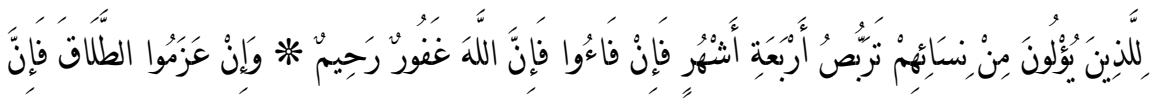

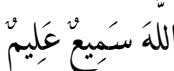

"Kepada orang-orang yang meng-ila' isterinya diberi tangguh empat bulan (lamanya). Kemudian jika mereka kembali (kepada isterinya, maka sesungguhnya Allah Maha Pengampun lagi Maha

\footnotetext{
${ }^{17}$ Jashshash, Ahkam al-Qur'an, Jilid 1, hlm. 199
}

Penyayang. Dan jika mereka berazam (bertetap hati) untuk thalak, maka sesungguhnya Allah Maha Mendengar lagi Maha Mengetahui. (Q.S. al-Baqarah: 226-227).

Dalam menafsirkan ayat tersebut ada beberapa point yang dapat dikaji dalam tulisan, yaitu:

\section{a. Pengertian ila'}

Menurut bahasa ila' sama dengan الحلف yaitu sumpah. Dalam istilah syara' ila' adalah sumpah seorang suami meninggalkan hubungan seksual/senggama dengan isterinya yang berakibat cerai apabila habis masa yang ditentukan.

Dari pengertian ila' yang telah dikemukakan al-Jashshash di atas, ia menjelaskan bahwa ila' itu hanya terjadi apabila suami bersumpah tidak menggauli isterinya. Adapun suami bersumpah meninggalkan sesuatu dari isterinya, seperti tidak berbicara, pisah ranjang dan lain sebagainya, tidak dinamakan ila'. Karena dalam sumpah ila' tersembunyi makna hubungan seksual/senggama. Demikian pula yang dimaksud dengan kembali dalam ayat 226 surat al-Baqarah tersebut adalah kembali menggauli isteri sesudah bersumpah tidak menggaulinya. Ia juga menguatkan argumentasinya dengan atsar yang berasal dari Anas bin Malik. Anas bin Malik mempunyai seorang isteri yang buruk perangainya, kemudian ia pisah ranjang selama lima atau enam bulan. Setelah itu ia kembali kepada isterinya, hal ini tidak dipandangnya sebagai ila'.18 Menurut al-Jashshash, hal ini membuktikan bahwa ila' itu hanya terjadi pada sumpah suami tidak menggauli isterinya.

\section{b. Batasan sumpah}

18 Adapun atsar yang berasal dari Anas bin Malik tersebut adalah:

عن الحسن أن أس ابن مالك كانت عنده امرأة فى خلفها سوء فكان هيجرها خمسة أشهر وستة أشهر ثم برجع إيها 
Menurut al-Jashshash, ila' itu terjadi apabila seorang suami bersumpah tidak menggauli isterinya selama empat bulan. Namun apabila suami bersumpah tidak menggauli isterinya kurang dari batas minimal empat bulan, maka ini tidak dapat dinamakan ila'. Demikian pula halnya tidak termasuk ila' apabila suami tidak menggauli isterinya tanpa dibarengi sumpah meskipun waktunya lebih dari empat bulan. Karena dalam ayat al-Qur'an yang menjadi dasar hukum ila' mengandung pengertian ila' itu suami bersumpah tidak menggauli isterinya selama empat bulan.

\section{c. Akibat hukum ila'}

Dalam kasus ila' ada dua kemungkinan hukuman yang akan didapatkan seorang suami, yaitu: pertama, hukum ukhrawi, yakni suami berdosa jika tidak kembali kepada isterinya dalam masa empat bulan tersebut. Kedua, hukum duniawi, yaitu jika suami kembali kepada isterinya, berarti ia telah melanggar sumpah, dan karena itu ia harus membayar kifarat sumpah berupa memberi makan sepuluh fakir miskin dalam satu hari atau memberi pakaian mereka atau memerdekakan seorang budak. Apabila salah satu diantara tiga pilihan tersebuit tidak dapat dipenuhinya karena miskin, maka ia wajib berpuasa selama tiga hari berturut-turut. Kifarat sumpah ini sebagaimana disebut dalam al-Qur'an surat al-Maidah ayat 89 sebagai berikut:

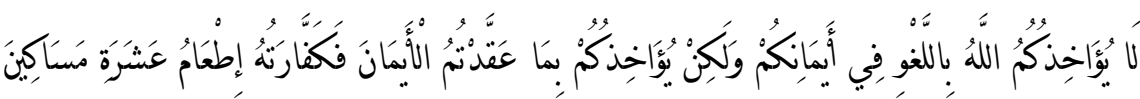

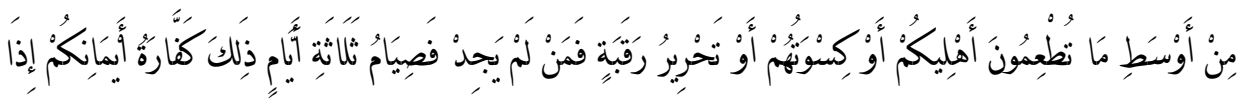

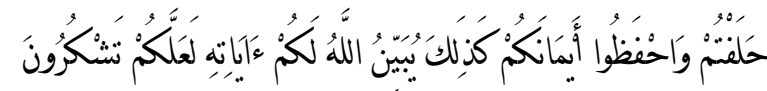

"Allah tidak menghukum kamu disebabkan sumpah-sumpahmu yang tidak dimaksud (untuk bersumpah), tetapi Dia menghukum kamu disebabkan sumpah-sumpah yang kamu sengaja, maka kaffarat (melanggar) sumpah itu, ialah memberi makan sepuluh orang miskin, yaitu dari makanan yang biasa kamu berikan kepada keluargamu, atau memberi pakaian kepada mereka atau memerdekakan seorang budak. Barangsiapa tidak sanggup melakukan yang demikian, maka kaffaratnya puasa selama tiga hari. Yang demikian itu adalah kaffarat sumpah-sumpahmu bila kamu bersumpah (dan kamu langgar). Dan jagalah sumpahmu. Demikianlah Allah menerangkan kepadamu hukum-hukum-Nya agar kamu bersyukur (kepada-Nya). (Q.S. al-Maidah: 89)

Menurut al-Jashshash perceraian yang terjadi akibat ila', statusnya talak bain kubra. Dengan kata lain apabila mereka ingin kembali lagi sebagai suami isteri, maka harus dilakukan akad yang baru dengan mahar yang baru pula.

Adapun cara kembali kepada isteri yang di ila, al-Jashshash berpegang teguh pada pemahaman tekstual ayat yakni faik menurut pengertian bahasa ialah kembali kepada sesuatu seperti yang terdapat dalam firman Allah:

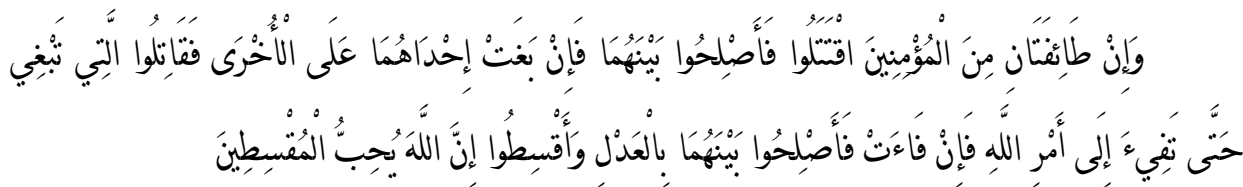

"Dan jika ada dua golongan dari orang-orang mu'min berperang maka damaikanlah antara keduanya. Jika salah satu dari kedua golongan itu berbuat aniaya terhadap golongan yang lain maka perangilah golongan yang berbuat aniaya itu sehingga golongan itu kembali kepada perintah Allah; jika golongan itu telah kembali (kepada perintah Allah), maka damaikanlah antara keduanya dengan adil dan berlaku adillah. Sesungguhnya Allah menyukai orang-orang yang berlaku adil.”. (Q.S. al-Hujarat ayat 9).

Yaitu kembali berbuat adil yang merupakan perintah Allah. Dengan demikian apabila pengertian faik itu kembali kepada sesuatu, maka kembalinya suami kepada isteri yang telah di-ila'-nya telah dapat 
dianggap sah apabila ia telah menyatakan kembali dan membatalkan sumpahnya baik ia mampu menggauli isterinya ataupun tidak.

\section{Menggunakan Hadis Sebagai Penafsir Ayat al-Qur'an}

Pada corak penafsiran bi al-ma'tsur, hadis sangat dominan dalam menjelaskan makna ayat al-Qur'an. Al-Jashshash sebagai seorang ulama tentunya sangat memahami kedudukan hadis sebagai penjelas al-Qur'an. Untuk melihat contoh penggunaan hadis dalam menafsirkan al-Qur'an dapat dilihat bahwa ketika menafsirkan ayat tentang wasiat dalam al-Qur'an (al-Baqarah: 180) al-Jashshash mengemukakan dua hadis yang menjelaskan kewajiban wasiat kepada orang tua dan keluarga terdekat, yaitu:

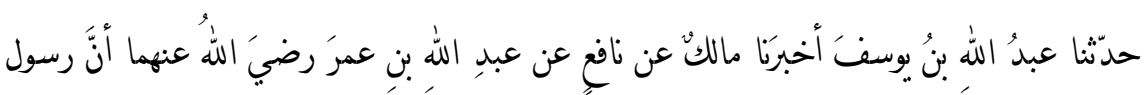

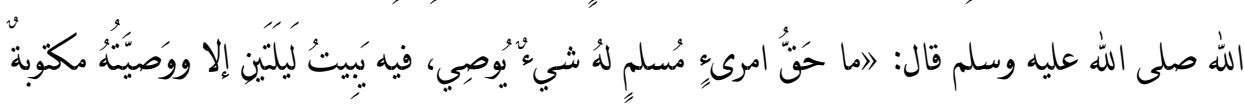

"Abdullah bin Yusuf menceritakan kepada kami, Malik menceritakan dari Nafi' dari Abdullah bin Umar r.a; sesungguhnya rasulullah saw bersabda: tidak ada hak seorang muslim yang memiliki harta untuk diwasiatkan dan ia bermalam dua malam kecuali ada wasiatnya yang tertulis. (H.R. Bukhari)

Hadis di atas menjelaskan begitu pentingnya pelaksanaan wasiat sehingga seorang jenazah dibenarkan untuk disemayamkan selama dua malam kalau ada wasiat yang belum dilaksanakan. Selain hadis diatas, al-Jashshash juga mengungkapkan hadis lain, yaitu:

${ }^{19}$ Imam Abu Abdillah Muhammad bin Ismail bin Ibrahim bin Mughirah bin Bazdari al-Bukhari, al-Ja'fiy (Selanjutnya ditulis Bukhari), Shabih Bukhari, (Beirut: Daar al-Fikr, 1995), Jilid 2, hlm. 149

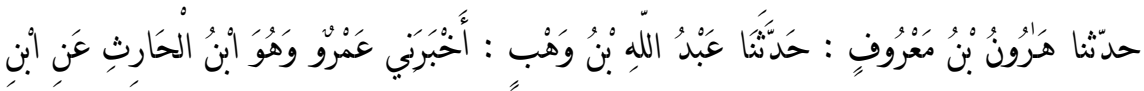

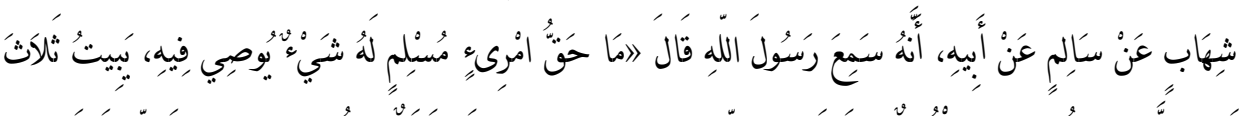

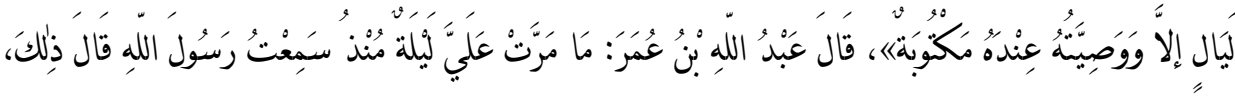

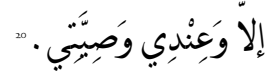

"Harun bin Ma'ruf bercerita kepada kami, bercerita kepada kami Abdullah bin Wahab, bercerita kepadaku Amr yakni Ibn alHarits dari Ibn Syihab dari Salim dari bapaknya, sesungguhnya ia mendengar rasulullah saw bersabda: tidak halal bagi seorang mukmin bermalam tiga malam kecuali ada wasiatnya yang tertulis". Abdullah ibn Umar berkata "Semenjak Aku mendengarkan rasulullah saw menyatakan demikian, aku tidak pernah membiarkan jenazah disemayamkan selama semalam kecuali ada wasiat".

Kedua hadis di atas dipahami al-Jashshash sebagai penafsir ayat tentang wasiat dan sekaligus menunjukkan wajibnya menunaikan wasiat terhadap orang tua dan kerabat dekat.

\section{Tidak Menerima Nasakh al-Qur'an}

Al-Jashshash berpendapat bahwa pada ayat ini tidak berlaku nasakh al-Qur'an dengan al-Qur'an sebagaimana pandangan kebanyakan ulama termasuk Syafi'i yang menyatakan bahwa ayat 180 surat al-Baqarah tersebut telah di nasakh oleh ayat 7 surat an-Nisa' tentang kewarisan ${ }^{21}$, serta dengan hadis. ${ }^{22} \mathrm{Al}$-Jashshash mengatakan

20 Imam Husain Muslim bin al-Hajjaj al-Qusyairi (Selanjutnya ditulis Muslim), Shahih Muslim, (Kairo: Daar al-Hadits, 1982), Jilid 3, hlm. 1250

${ }^{21}$ Ayat yang digunakan Syafii untuk menasakh hukum wasiat adalah surat alNisa' ayat 7 sebagai berikut:

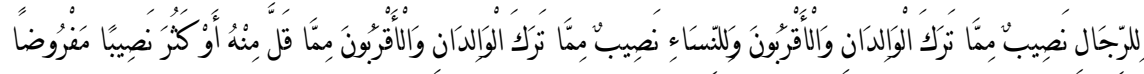


tidak ada indikasi yang menunjukkan bahwa ayat tentang kewarisan tersebut menasakh ayat tentang wasiat. Menurutnya kedua pemahaman ayat ini masih dapat dikompromikan, karena kedua materi hukum tersebut berbeda dan dapat dilaksanakan sesuai dengan ketentuannya masing-masing tanpa harus menghapus salah satu materi hukumnya.

Kalau ditinjau dari segi pelaksanaannya, warisan baru dapat dibagikan kepada ahli waris apabila telah dilaksanakan wasiatnya. Selanjutnya al-Jashshash mengatakan tidak ada larangan membagikan harta warisan terhadap orang yang telah menerima harta wasiat. Dengan demikian menurutnya menasakh ayat wasiat dengan ayat tentang kewarisan tidak dapat diberlakukan.

Menurut sebahagian ulama, ayat tersebut sebahagiannya dinasakh oleh ayat tentang kewarisan, yang boleh diberikan wasiat adalah ahli waris yang tidak ada bahagiannya, baik karena terhijab ataupun zawil arham. Menurut al-Jashshash menasakh sebahagian makna ayat tentunya tidak dapat diterima. Karena bagaimana mungkin

"Bagi laki-laki ada hak bagian dari harta peninggalan ibu-bapa dan kerabatnya, dan bagi wanita ada hak bagian (pula) dari harta peninggalan ibu-bapa dan kerabatnya, baik sedikit atau banyak menurut bahagian yang telah ditetapkan". (Q.S. an-Nisa': 7)

22 Adapun hadis yang mereka jadikan untuk menasakh ayat al-Qur'an tentang wasiat adalah:

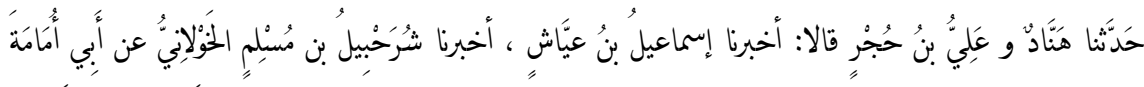

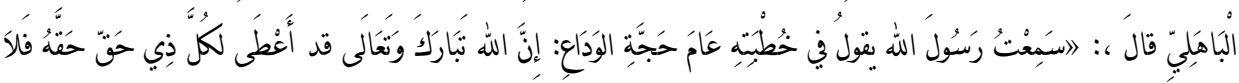

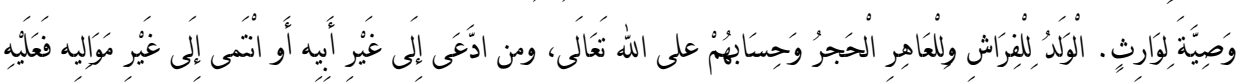

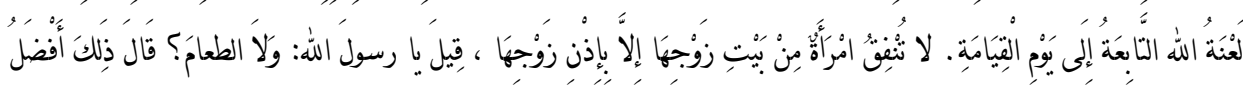

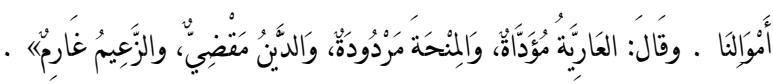

Lihat Turmudzi, Sunan al-Turmudzi, (Beirut: Daar al-Kutub al-Ilmiah, 1992), jilid 6, hlm. 226 dalam satu ayat, sebahagian pengertiannya diterima sementara sebahagiannya tidak.

Sedangkan menasakh ayat wasiat dengan hadis menurut alJashshash tidak dapat diterapkan. Dalam hal ini lebih tegas lagi ia mengatakan tidak boleh menasakh al-Qur'an dengan hadis ahad. AlQur'an adalah qath'iy al-tsubut sementara hadis adalah z̧banniy al-tsubut. Selain itu, hadis yang digunakan untuk menasakh ayat tentang wasiat tersebut adalah hadis munqathi'. Tentunya ia tidak dapat diterima hadis munqathi' maupun hadis mursal untuk menasakh al-Qur'an. Dengan demikian, jelaslah hukum wajib berwasiat kepada orang tua dan kerabat tetap dapat diberlakukan.

\section{Iddah}

Dalam kitab tafsirnya, al-Jashshash membahas kajian iddah dalam lima bentuk sesuai dengan ayat-ayat yang berbicara tentang iddah tersebut. Dalam kajian itu penulis juga hanya memaparkan konsep-konsep iddah sebagaimana yang dimuat al-jashshash. Untuk lebih jelasnya dapat dirinci sebagai berikut:

\section{a. Iddah wanita yang masih haid}

Iddah wanita yang masih haid adalah wanita yang cerai hidup dengan suaminya dan ia masih mengalamihaid. Iddah seperti ini dipahami dari Firman Allah SWTdalam surat al-Baqarah ayat 228 sebagai berikut:

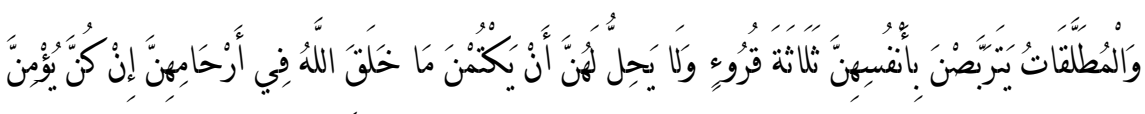

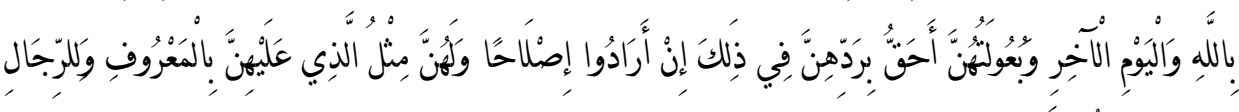

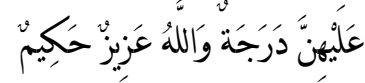

"Wanita-wanita yang ditalak hendaklah menahan diri (menunggu) tiga kali quru. Tidak boleh mereka menyembunyikan apa yang diciptakan Allah dalam rahimnya, 
jika mereka beriman kepada Allah dan hari akhirat. Dan suamisuaminya berhak merujukinya dalam masa menanti itu, jika mereka (para suami) itu menghendaki ishlah. Dan para wanita mempunyai hak yang seimbang dengan kewajibannya menurut cara yang ma`ruf. Akan tetapi para suami mempunyai satu tingkatan kelebihan daripada isterinya. Dan Allah Maha Perkasa lagi Maha Bijaksana.”. (Q.S. al-Baqarah: 228)

Dalam menafsirkan quru' pada ayat ini, al-Jashshash mengatakan quru' itu adalah nama lain dari darah ketika telah jelas keluarnya pada seorang wanita yang haid. Ia juga mengatakan waktu yang ada kaitannya dengan hukum adalah waktu haid. Karena waktu haid itu dapat memastikan apakah seorang wanita itu hamil atau tidak. Hal ini sebagaimana diungkapkan Allah:

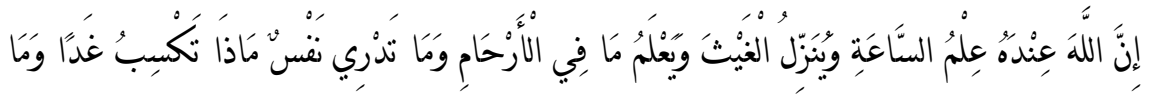

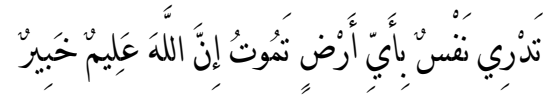

"Sesungguhnya Allah, hanya pada sisi-Nya sajalah pengetahuan tentang Hari Kiamat; dan Dia-lah Yang menurunkan hujan, dan mengetahui apa yang ada dalam rahim. Dan tiada seorangpun yang dapat mengetahui (dengan pasti) apa yang akan diusahakannya besok. Dan tiada seorangpun yang dapat mengetahui di bumi mana dia akan mati. Sesungguhnya Allah Maha Mengetahui lagi Maha Mengenal ".(Q.S. Lukman: 34)

Al-jashshash juga menjelaskan bahwa salah satu hikmah disyariatkannya $i d d a h$ adalah untuk mengetahui keadaan rahim wanita apakah ia mengandung janin atau tidak, dan kalau dia mengandung janin tentu ia tidak haid lagi.

Selanjutnya al-Jashshash mengungkapkan bahwa menurut bahasa quru' itu memang mengandung dua makna, yaitu makna hakiki dan majazi. Makna hakiki dari quru' adalah haid dan makna majazinya adalah suci. Ia menjelaskan apabila makna hakiki dapat diterapkan, maka makna hakiki lebih diutamakan daripada makna majazi. Berkenaan dengan makna quru' dalam ayat ini tidak tepat kalau digunakan makna majazi (suci) karena keadaan suci itu sendiri hanya ada pada wanita monopause atau wanita yang belum baligh. Ini dapat dibuktikan dalam al-Qur'an di mana Allah tidak menetapkan iddah tiga kali quru' terhadap kedua golongan wanita di atas, tetapi iddahnya tiga bulan. Ini menurutnya suatu hal yang menunjukkan bahwa makna hakiki lebih tepat ditrerapkan dari pada makna majazi. ${ }^{23}$

Al-Jashshash juga mngemukakan hadis untuk memperkuat argumentasinya tentang makna quru' itu haid. Nabi Muhammad SAW bersabda:

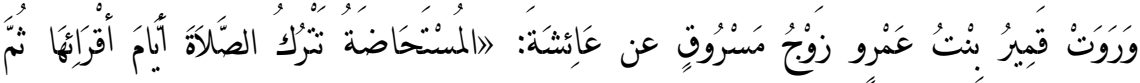

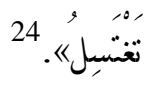

"Diriwayatkan dari Qamir binti 'Amr isteri Masruq dari 'Aisyah: Wanita yang mustahadhah meninggalkan shalat pada waktu haidnya sampai ia mandi". (H.R. Abu Daud)

Nabi juga berkata kepada Fatimah binti Abu Hubaisy:

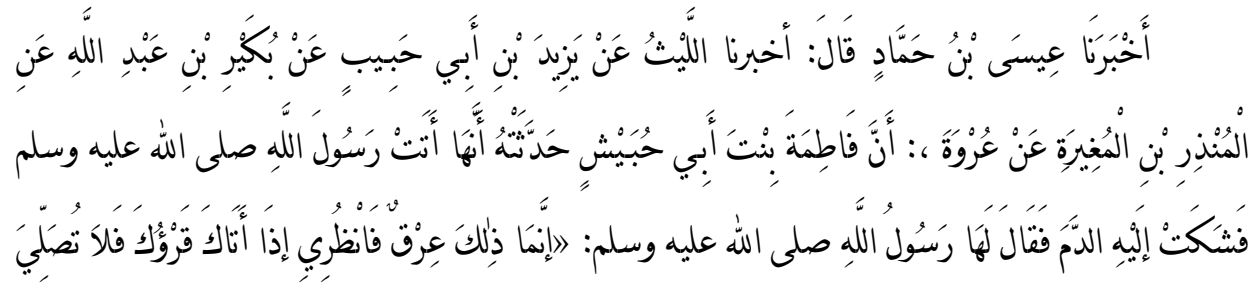

${ }^{23}$ Jashshash, Abkam al-Qur'an, jilid 1, hlm. 441

${ }^{24}$ Imam al-Hafizh Abu Daud Sulaiman ibn 'Asy'asyi (selanjutnya ditulis Abu Daud), Sunan Abu Daud, (Beirut: Daar al-Fikr, t.th.), Jilid 1, hlm. 74 


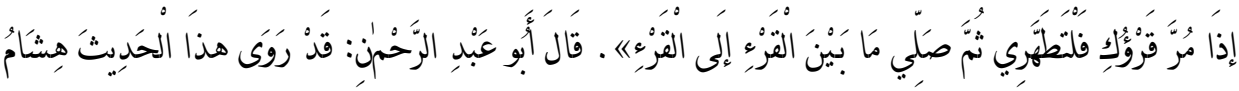

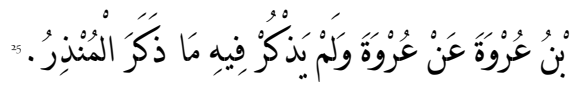

"Isa bin Hammad bercerita kepada kami, ia berkata: al-Laits menceritakan kepada kami dari Yazid bin Abi Habib dari Bukair bin Abdullah dari Munzir bin Mughirah dari 'Urwah Sesungguhnya Fatimah binti Abi Hubaisy menceritakan sesungguhnya ia pernah mendatangi rasulullah SAW, ia mengadukan kepada rasulullah SAW persoalan darah, rasulullah SAW bersabda: sesungguhnya itu adalah keringat, maka perhatikanlah apabila datang haidmu jangan shalat, apabila haidmu selesai bersucilah, kemudian shalat antara waktu satu haid dengan haid berikutnya".

Dari kedua hadis ini tampak jelas bahwa quru' itu digunakan Nabi untuk menyebut haid.

Selain kedua hadis yang telah dikemukakan di atas, masih ada lagi hadis yang menurut al-Jashshash menjelaskan makna quru' itu haid. Hadis tersebut sebagai berikut:

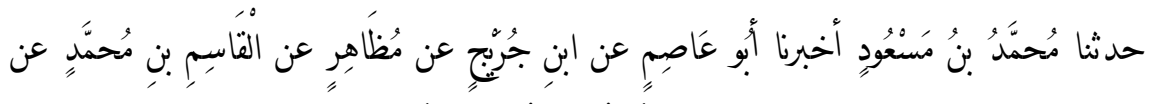

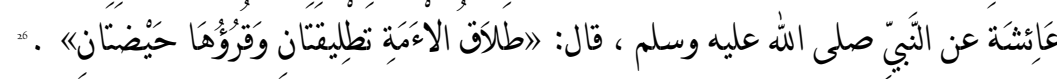

"Muhammad bin mas'ud menceritakan kepada kami, ia berkata: Abu Ashim menceritakan kepada kami dari Ibnu Juraij dari Muzhahir bin Aslam dari Qasim bin Muhammad dari Aisyah, dari Nabi Muhammad SAW ia bersabda: Thalak hamba dua kali dan quru'nya dua kali haid". (H.R. Abu Daud).
Juga hadis yang berasal dari Ibnu Umar dari Nabi SAW ia bersabda: Thalak seorang hamba dua kali dan iddahnya dua kali haid.

Al-Jashshash mengemukakan bahwa ulama sepakat terhadap pemahaman kedua hadis ini, yakni iddah seorang hamba perempuan separoh dari wanita merdeka. Kalau dalam dalam hadis ini dipahami iddah seorang hamba perempuan dua kali haid, tentu iddah perempuan merdeka, juga dihitung tiga kali haid, bukan tiga kali suci.

Selain itu iddah disyariatkan sebagai waktu untuk menunggu. Nabi menjadikan masa haid untuk menunggu bagi hamba perempuan. Kalau waktu menunggu bagi hamba perempuan adalah masa haid, tentu waktu menunggu bagi wanita merdeka juga masa haid, karena tujuan disyariatkannya waktu menunggu itu sama saja bagi wanita merdeka dengan hamba perempuan.

Dari berbagai argumentasi yang dikemukakannya sebagaimana telah di ungkapkan di atas, tampaknya al-Jashshash lebih cenderung menafsirkan kata quru' dengan makna haid. Dengan demikian, iddah wanita yang diceraikan suaminya adalah tiga kali haid.

\section{b. Iddah wanita yang tidak haid}

Yang dimaksud tidak haid di sini adalah wanita yang tidak haid lagi karena usia lanjut (menopause) atau wanita yang belum haid karena belum sampai usia baligh. Dalam hal ini tampaknya aljashshash sepakat dengan ulama lain bahwa iddah wanita yang tidak haid adalah tiga bulan. Pandangan ini beranjak dari firman Allah dalam surat at-Thalak ayat 4 :

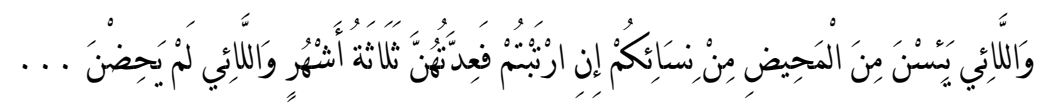

"Dan wanita-wanita yang tidak haid lagi di antara perempuanperempuanmu, jika kamu ragu tentang masa iddahnya, maka iddah mereka adalah tiga bulan dan begitu pula wanita-wanita yang belum haid (Q.S. al-Thalak: 4) 


\section{c. Iddah wanita hamil}

Mengenai iddah wanita hamil sebagaimana juga ulama lain, alJashshash menjelaskan iddahnya sampai melahirkan. Adapun landasan hukumnya adalah firman Allah dalam surat al-Thalak ayat 4, yaitu:

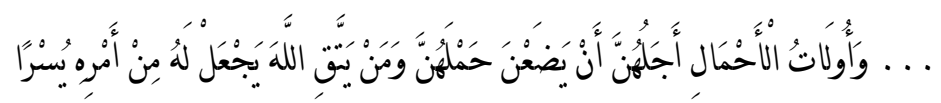

"Dan wanita-wanita yang hamil, waktu iddah mereka adalah sampai mereka melahirkan (Q.S al-Thalak: 4)

Al-jashshash memahami ayat ini berlaku umum bagi wanita hamil untuk semua bentuk perceraian, baik cerai hidup maupun cerai mati. Dengan pemahaman ini menirut al-jashshash bahwa addah wanita hamil yang kematian suami tetap sampai melahirkan. Untuk menguatkan pendapatnya ia mengemukakan hadis tentang kisah syuba'ah, yaitu: "Dari Muhammad bin Ishak dari syuba'ah bahwa ia melahirkan dua belan setelah suaminya meninggal, lalu ia bertanya kepada Rosul SAW. Dan Rasul berkata kepadanya "menikahlah engkau".

Berdasarkan hadis ini menurut al-jashshash jelaslah iddah wanita hamil yang kematian suami adalah sampai ia melahirkan.

\section{d. Iddah wanita yang belum di gauli}

Wanita yang dicerai sebelum digauli maka tidak ada baginya iddah berdasarkan firman Allah dalam surat al-Ahzab ayat 49, yaitu:

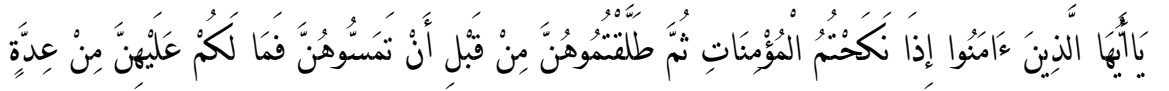

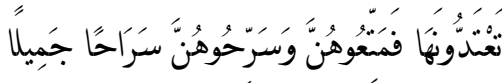

"Hai orang-orang yang beriman apabila kamu menikahi wanita yang beriman kemudian kamu ceraikan sebelum kamu menggaulinya, maka tidfak wajib bagi mereka iddah.(Q.S. Al-Ahzab: 49).

\section{e. Iddah wanita kematian suami}

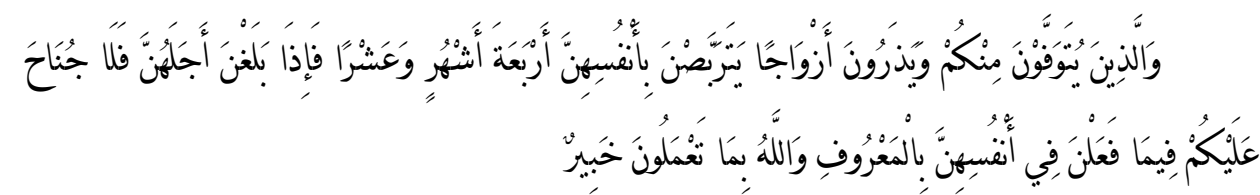

"Orang-orang yang meninggal dunia di antaramu dengan meninggalkan isteri-isteri (hendaklah para isteri itu) menangguhkan dirinya (ber iddah) empat bulan sepuluh hari. Kemudian apabila telah habis iddahnya, maka tiada dosa bagimu (para wali) membiarkan mereka berbuat terhadap diri mereka menurut yang patut. Allah mengetahui apa yang kamu perbuat". (Al-Baqarah: 234).

\section{Metode Penafsiran Ayat Hukum al-Jashshash}

Sebagaimana dijelaskan sebelumnya al-Jashshash hidup pada zaman perkembangan ilmu pengetahuan. Hal ini sangat berpengaruh dalam membentuk pola pikirnya, sehingga ia menjadi ulama terkenal pada masanya. Sebagai seorang mufassir. Al-jashshash tampaknya menggabungkan antara corak manqul/ ma'tsur dengan corak penafsiran $m a ' q u l$. Ini terlihat dari penafsirannya terhadap ayat tentang wasiat, ila' dan iddah yang di kemukakan dalam tulisan ini.

Lebih spesifik metode penafsiran ayat hukum yang dilakukan alJashshash adalah: pertama, mengemukakan ayat yang akan ditafsirkan; kedua, memberikan penjelasan makna etimologi dan dikuatkan dengan ayat al-Qur'an lain, hadis maupun pendapat sahabat; ketiga, mencantumkan masalah fiqhiyah yang mungkin dipahami dari ayat yang ditafsirkan; keempat, mengemukakan pendapat ulama beserta argumentasi yang mereka gunakan; kelima, menganalisa pendapat ulama yang dikemukakan serta menentukan pendapatnya sendiri.

Jika dilihat pemikiran fiqh yang merupakan hasil pemikirannya terhadap ayat-ayat yang dikemikakan diatas, ia menganut beberapa kerangka berpikir seperti:

\section{Teguh dalam Menjaga Eksistensi al-Qur'an}


Sebagai fuqaha, al-Jashshash mengistinbatkan hukum pada ayatayat yang di tafsirkannya dan sebagai mufassir tampaknya ia sangat menjaga eksistensi al-Quran. Sikap al-jashshash dalam membela dan menjaga eksistensi al-Quran terlihat dari keengganannya menewrima hadis sebagai penasakh al-Quran. Dengan jelas ia mengatakan tidak boleh menasakh al-Quran dengan hadis.

Pendapat ini dapat dibuktikan dari sikatnya ketika menafsirkan ayat 180 surat al-Baqarah. Ia tetap memberlakukan kandungan hukum yang terdapat pada ayat tersebut yang menjelaskan wajibnya berwasiat terhadap ibu bapak dan kerabat. Hal ini tidak menerima nasakh terhadap ayat ini, baik nasakh dengan ayat maupun nasakh dengan hadis. Tetapi ini bukan berarti ia tidak menerima nasakh sama sekali, karena dalam kasus yang berbeda seperti masalah iddah wanita yang kematian suami ia mengakui bahwa iddah empat bulan sepuluh hari itu sebagai penasakh iddah setahun.

\section{Selektif dalam Penggunaan Nash}

Al-Jashshash sangat selektif dalam penggunaan hadis apabila berhadapan dengan al-Qur'an. Hal inipun sebagai akibat dari keteguhannya dalam menjaga dan mempertahankan eksistensi alQuran. Namun bukan berarti ia tidak menggunakan hadis sebagai sumber hukum, bahkan dalam hal lain ia menggunakan atsar untuk memperkuat ijtihadnya, seperti atsar yang berasal dari Anas bin Malik yang pisah ranjang dengan isterinya selama lima atau enam bulan, tetapi tidak mengaitkannya dengan sumpah kemudian Anas bin Malik tidak memandangnya sebagai ila'. Atsar ini dipakai al-Jashshash untuk menguatkan pendapatnya bahwa baru dinamakan ila' apabila dibarengi dengan sumpah. Dalam masalah ini ia sependapat dengan kebanyakan ulama fiqh dan berbeda dengan Ibnu Umar. Ia mengatakan pisah ranjang apabila lewat empat bulan dinamakan ila'. Selain itu dalam beberapa kasus yang dikemukakan sebelumnya ia juga menggunakan hadis.
Pada kasus iddah wanita yang cerai dengan suaminya dan masih haid, ia menafsirkan quru' dengan haid. Untuk hal ini, al-Jashshash memakai hadis tentang iddah hamba perempuan sebagai landasan untuk meng-qias-kan wanita merdeka dengan hamba. Dengan demikian ia sependapat dengan Umar bin Khattab, Ali bin Abi Thalib, Abu Musa al-Sy'ari, Ibnu Mas'ud dan juga Abu Hanifah serta fuqaha Irak lainnya.

Kalau dilihat bentuk pemikiran hukum al-Jashshash di atas jika dihubungkan dengan corak pemikiran fiqh dalam Islam, maka pemikiran fiqh al-Jashshash tampaknya lebih dekat dengan corak pemikiran figh rasional (ahl al-ra'y). Hal ini terlihat dari kesungguhannya membela dan mempertahankan eksistensi al-Qur'an dan sangat selektif dalam penggunaan hadis. Meskipun demikian sebagai ulama besar ia tidak hanya menyadur pendapat yang ada pada mazhabnya, tetapi juga menginstinbatkan hukum sebagaimana ulama lainnya, sehingga terkadang ada pendapatnya yang tidak sesuai dengan mazhabnya.

\section{Kesimpulan}

Dari pembahasan di atas, tulisan ini dapat disimpulkan bahwa dalam menafsirkan ayat-ayat hukum, al-Jashshash mengkombinasikan corak penafsiran bi al-ma'tsur dengan bi al-ra'y. Adapun metode yang digunakan adalah: pertama, mengemukakan ayat yang akan ditafsirkan, kedua, memberikan penjelasan makna etimologi dan dikuatkan dengan ayat al-Qur'an lain, hadis maupun pendapat sahabat; ketiga, mencantumkan masalah fiqhiyah yang mungkin dipahami dari ayat yang ditafsirkan; keempat, mengemukakan pendapat ulama beserta argumentasi yang mereka gunakan; kelima, menganalisa pendapat ulama yang dikemukakan serta menentukan pendapatnya sendiri.

\section{Bibliografi}

'Allamah al-Maula Mushthafa ibn Abdillah al-Qusthanthiniy al-Hanafi, Kasyf al-Zhunun, (Beirut: Daar al-Fikr, 1994). 
Khairuddin, Metode Penafsiran Ayat Hukum ...

Al-Jashshash, Abkam al-Qur'an, (Beirut: Daar al-Fikr, 1993).

Departemen Agama RI., Ensiklopedi Hukum Islam, (Jakarta: PT. Ikhtiar Baru Van Hoeve, 1999).

Imam Abu Abdillah Muhammad bin Ismail bin Ibrahim bin Mughirah bin Bazdari al-Bukhari, al-Ja'fiy (Selanjutnya ditulis Bukhari), Shahih Bukhari, (Beirut: Daar al-Fikr, 1995).

Imam al-Hafizh Abu Daud Sulaiman ibn 'Asy'asyi, Sunan Abu Daud, (Beirut: Daar al-Fikr, t.th.).

Imam Husain Muslim bin al-Hajjaj al-Qusyairi (Selanjutnya ditulis Muslim), Shahih Muslim, (Kairo: Daar al-Hadits, 1982).

Imam Nasai, Sunan Nasai, (Beirut: Daar al-Ma'rifah, 1991).

M. Quraish Shihab, Membumikan al-Qur'an, (Bandung: Mizan, 1994).

Mani' Abdul Halim Mahmud, Manahij al-Mufassirin, (Kairo: Daar alKitab al-Mishr, 1978).

Moh. Amin Suma, Pengantar Tafsir Abkam, Jakarta: Rajawali Pers, 2001).

Muhammad Husain al-Dzahabi, Tafsir wa al-Mufassirun, (Kairo: Daar al-Kutub al-Hadisah, 1976).

Turmudzi, Sunan al-Turmudzi, (Beirut: Daar al-Kutub al-Ilmiah, 1992).

Yusuf Qardhawi, Kaifa Nata'ammalu Ma'a al-Qur'an al-'Azbim, alih bahasa oleh Abdul Hayyi al-Kattaniy, (Jakarta: Gema Insani Press, 1999).

Mushtafa al-Shawi al-Juwaini, Manahij fi al-Tafsir, (Iskandariyah: Daar al-Shadir, t.th.)

Shubhi al-Shalih, Mabahits fi Ulum al-Qur'an, (Beirut: Daar al-Ilm li alMalayyin, t.th.) 